\title{
Long-term and Storm-related Shoreline Change Trends in the Florida Gulf Islands National Seashore
}

U.S. DEPARTMENT OF THE INTERIOR

U.S. GEOLOGICAL SURVEY

\section{Open-File Report 2007- 1392}

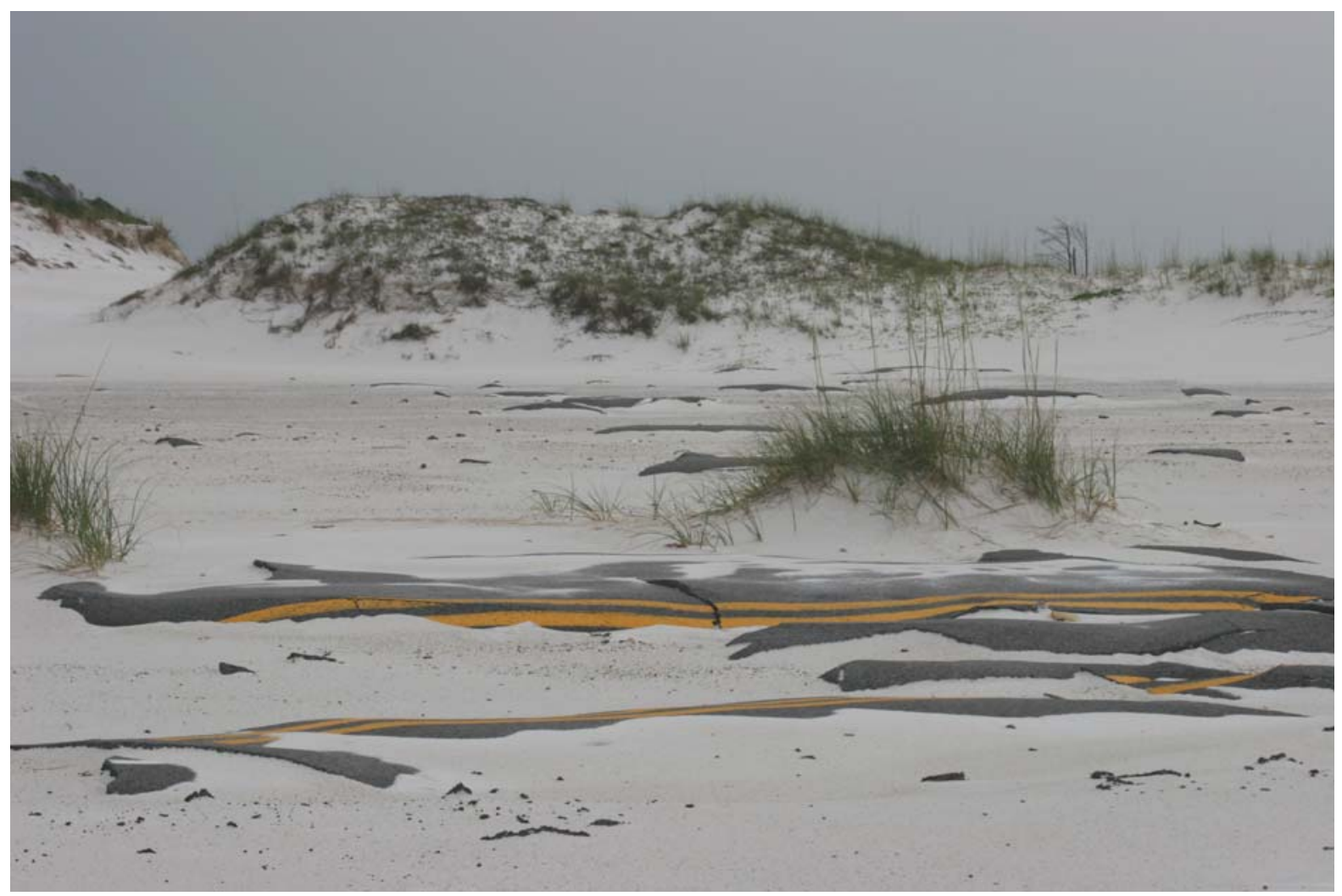




\section{Long-term and Storm-related Shoreline Change Trends in the Florida Gulf Islands National Seashore}

By Cheryl J. Hapke ${ }^{1}$ and Mark Christiano ${ }^{2}$

${ }^{1}$ U.S. Geological Survey, Department of Geosciences, University of Rhode Island, Kingston, RI 02881

2 Environmental Data Center, Department of Natural Resource Sciences, University of Rhode Island, Kingston, RI 02881

Open-File Report 2007-1392

U.S. DEPARTMENT OF THE INTERIOR

U.S. GEOLOGICAL SURVEY 


\section{U.S. Department of the Interior \\ Dirk Kempthorne, Secretary}

\section{U.S. Geological Survey \\ Mark Myers, Director}

For product and ordering information:

World Wide Web: http://www.usgs.gov/pubprod

Telephone: 1-888-ASK-USGS

For more information on the USGS-the Federal source for science about the Earth, its natural and living resources, natural hazards, and the environment: World Wide Web: http://www.usgs.gov

Telephone: 1-888-ASK-USGS

Suggested citation:

Hapke, C.J. and Christiano, M., 2007, Long-term and Storm-related Shoreline Change Trends in the Florida Gulf Islands National Seashore: U.S. Geological Survey Open-file Report 2007-1392, 18p.

Any use of trade, product, or firm names is for descriptive purposes only and does not imply endorsement by the U.S. Government.

Although this report is in the public domain, permission must be secured from the individual copyright owners to reproduce any copyrighted material contained within this report. 


\section{CONTENTS}

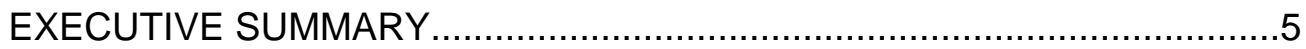

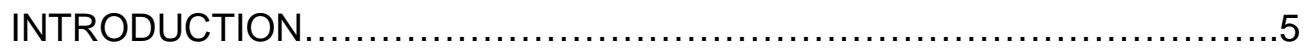

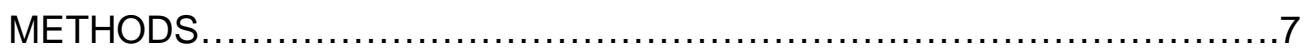

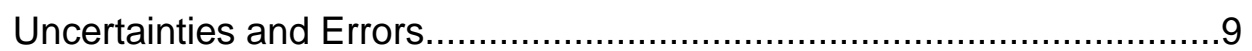

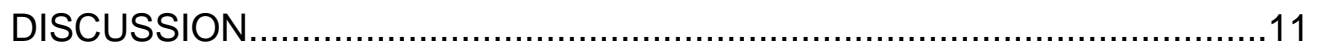

Fort Pickens Unit...............................................................

Santa Rosa Unit...........................................................13

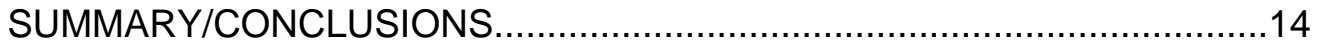

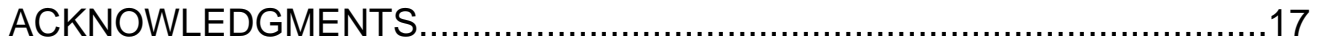

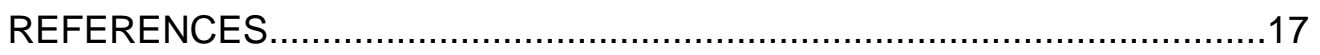

\section{LIST OF FIGURES}

Figure 1. Location map of the Gulf Islands National Seashore in Florida.

Figure 2. Shoreline change plots for the Fort Pickens unit.

Figure 3. Shoreline change plots for the Santa Rosa unit.

\section{LIST OF TABLES}

Table 1. Ages and sources of compiled shorelines.

Table 2. Maximum estimated positional and measurement errors for GUIS shorelines.

Table 3. Average and maximum erosion rates for GUIS. 


\section{EXECUTIVE SUMMARY}

Coastal erosion on Northern Gulf of Mexico barrier islands is an ongoing issue that was exacerbated by the storm seasons of 2004 and 2005 when several hurricanes made landfall in the Gulf of Mexico. Two units of the Gulf Islands National Seashore (GUIS), located on Santa Rosa Island, a barrier island off the Panhandle coast of Florida, were highly impacted during the hurricanes of 2004 (Ivan) and 2005 (Cindy, Dennis, Katrina and Rita). In addition to the loss of or damage to natural and cultural resources within the park, damage to park infrastructure, including park access roads and utilities, occurred in areas experiencing rapid shoreline retreat. The main park road was located as close as $50 \mathrm{~m}$ to the pre-storm (2001) shoreline and was still under repair from damage incurred during Hurricane Ivan when the 2005 hurricanes struck. A new General Management Plan is under development for the Gulf Islands National Seashore. This plan, like the existing General Management Plan, strives to incorporate natural barrier island processes, and will guide future efforts to provide access to units of Gulf Islands National Seashore on Santa Rosa Island.

To assess changes in island geomorphology and provide data for park management, the National Park Service and the U.S. Geological Survey are currently analyzing shoreline change to better understand long-term (100+ years) shoreline change trends as well as short-term shoreline impact and recovery to severe storm events. Results show that over an -140-year period from the late 1800s to May 2004, the average shoreline erosion rates in the Fort Pickens and Santa Rosa units of GUIS were $-0.7 \mathrm{~m} / \mathrm{yr}$ and $-0.1 \mathrm{~m} / \mathrm{yr}$, respectively. Areas of historic erosion, reaching a maximum rate of $-1.3 \mathrm{~m} / \mathrm{yr}$, correspond to areas that experienced overwash and road damage during the 2004 hurricane season.. The shoreline eroded as much as $\sim 60 \mathrm{~m}$ during Hurricane Ivan, and as much as $\sim 88 \mathrm{~m}$ over the course of the 2005 storm season. The shoreline erosion rates in the areas where the park road was heavily damaged were as high as $-70.2 \mathrm{~m} / \mathrm{yr}$ over the 2004-2005 time period. Additional post-storm monitoring of these sections of the island, to assess whether erosion rates stabilize, will help to parks to determine the best long-term management strategy for the park infrastructure.

\section{INTRODUCTION}

The Gulf Islands National Seashore (GUIS), in the northern Gulf of Mexico, is composed of a series of barrier islands that lie along the Florida Panhandle and Mississippi coasts. GUIS consists of seven barrier islands that extend along a total of $240 \mathrm{~km}$ of coast, with two in Florida (Perdido Key and Santa Rosa Island; Figure 1) and five in Mississippi. 
Santa Rosa Island is a low-profile, late Holocene barrier island (Otvos, 1982; Morton and others, 2004). Prior to the 2004-05 hurricanes, the island ranged in width from $160-1800 \mathrm{~m}$, and fordune elevations were in the $5 \mathrm{~m}$ range. The Gulf Islands in Florida have historically been more stable than their Mississippi counterparts with respect to shoreline change (Stone and others, 2004). In 1995, Santa Rosa Island was almost entirely overwashed by Hurricane Opal which made landfall just east of Pensacola Beach. Opal caused extensive erosion and removed dunes as high as 5 meters (Stone and others, 2004), leaving the island and park resources more susceptible to future storms and erosion. In 2004 and 2005, a series of large and catastrophic hurricanes and tropical storms again directly impacted GUIS causing extensive damage to the coastal barrier islands and to coastal infrastructure.

During such catastrophic events and/or storm seasons, dynamic but fragile barrier islands can become completely geomorphologically reconfigured, which directly affects habitat availability and functionality. Management of the highly impacted coastal resources in GUIS requires a working knowledge of how the system has changed. In order to understand the signal of severe storm shoreline change in the long-term record we assess whether the spatial patterns of the long-term erosion rates can indicate where future stormrelated hazards are greatest.

The objective of this research is to build on existing long-term data that are critical to the understanding of short-term storm response in the Gulf Islands in Florida. The intention of this study is to determine, based on long-term trends (>100 years) and short-term (storm or seasonal) changes, where high rates of shoreline erosion may occur during future severe storms and thus provide useful information on the placement and maintenance of park infrastructure. 


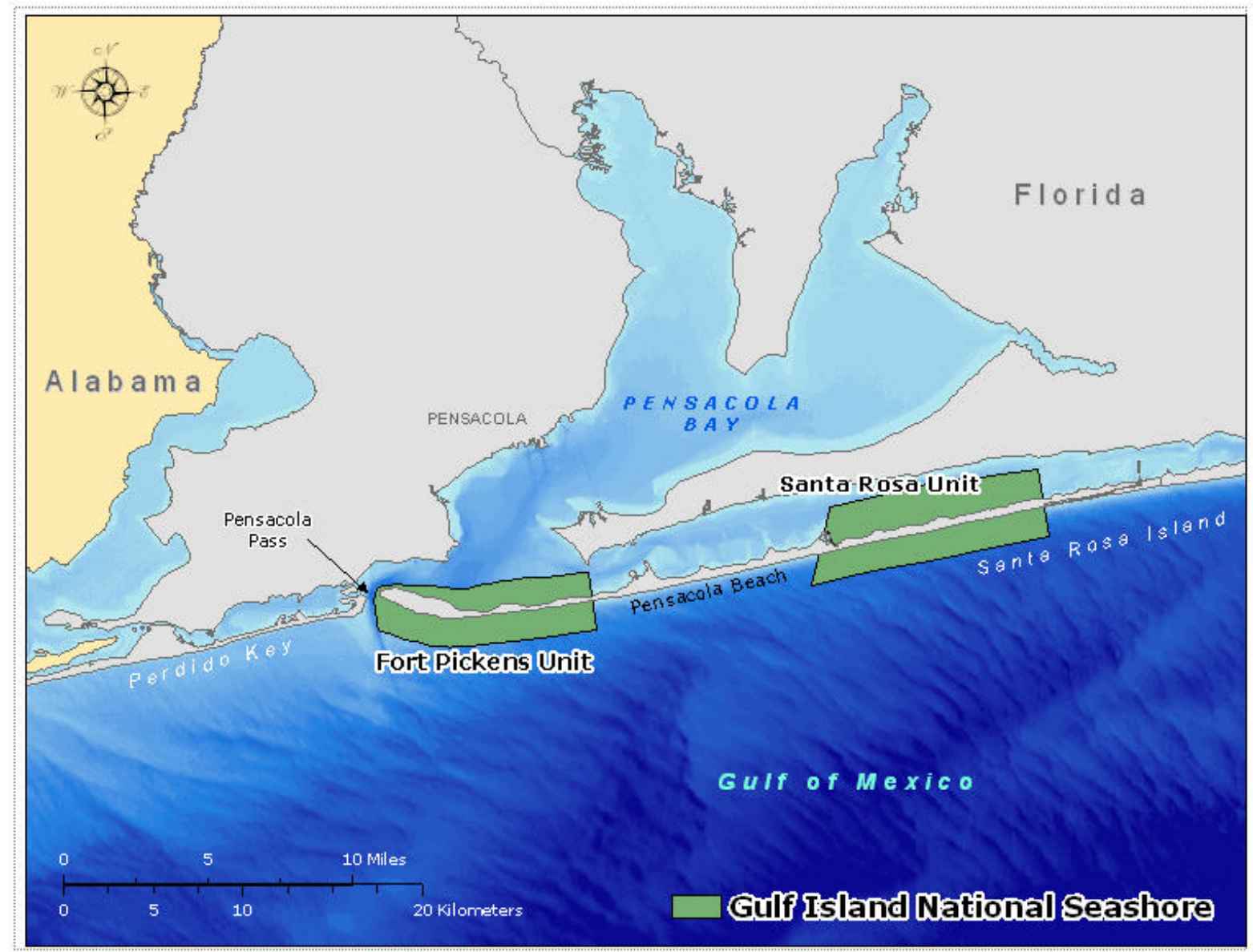

Figure 1. Location map of the Florida Units of the Gulf Islands National Seashore.

\section{METHODS}

The shoreline change rates used for this analysis are derived from both three historical time periods (1800s, 1930s and 1970s) and recent $(2001,2004,2005)$ lidar data. The 2001 data are available for download from Miller and others (2004). The more recent lidar shorelines (2004 and 2005) were either obtained from the USGS or a mean high water (MHW) shoreline was extracted in-house for this analysis. Table 1 outlines the years and the sources of the data used for the shoreline change analysis. The map data consist of three historical shorelines that were digitized from georeferenced National Ocean Service (NOS) T-sheets, and represent the field interpretation of a high water line (HWL) on the beach (Shalowitz, 1964). The dates of the oldest map-derived shorelines are 1856, 1858 and 1859 for the Santa Rosa unit, and 1871 for the Fort Pickens unit. For the 1930s and 1970s-era T-sheets, the dates of the map-derived shorelines are 1934, and 1978 for both units. The modern shorelines are mean high water (MHW) shorelines derived from lidar 
data. For the long-term ( $150 \mathrm{yr}$ ) shoreline change the most recent shoreline is from May 2004 lidar data. Morton and others (2004) used the historical maps and 2001 lidar data to produce shoreline change rates for the entire Gulf of Mexico, including Santa Rosa Island. However, there are several distinct differences between our analysis and theirs. We recalculated the shoreline change rates using the Digital Shoreline Analysis System (DSAS; Thieler and others, 2005), producing rates on shore-perpendicular transects spaced at $20 \mathrm{~m}$ intervals, compared to the $50 \mathrm{~m}$ spacing used by Morton and others (2004). We also included a fifth shoreline, from May 2004, in the long-term, pre-storms analysis.

Additionally, Morton and others (2004) did not account for the bias in the data that exists as a function of using different shoreline proxies, a HWL versus a MHW. A HWL shoreline is higher on the beach than the MHW shoreline which does not take total water level (wave run-up and tide height) into account (Ruggiero and others, 2003; Moore and others, 2006). If a correction is not applied, the shoreline change rates will have an accretionary bias. The proxy bias was calculated using methods developed by Ruggiero and others (2003) and Moore and others (2006), and ranged from 5.0 - $10.2 \mathrm{~m}$. The application of the proxy bias results in an overall increase in the erosion rate of $-0.1 \mathrm{~m} / \mathrm{yr}$ for the portion of Santa Rosa Island extending from Pensacola Pass to Navarre Beach.

In order to assess storm-driven shoreline change, we acquired pre-Hurricane Ivan (May 2004), post-Hurricane Ivan (Sept. 2004) and post-Hurricane Katrina (Sept. 2005) lidar data for Santa Rosa Island, from Pensacola Pass to Navarre Beach. Shorelines had been extracted from the pre- and post-Ivan lidar data by the USGS Center for Coastal and Wetland Studies. The shoreline from the most recent (post-Katrina) lidar data was extracted by researchers at the USGS Woods Hole Science Center (WHSC) specifically for this analysis. We used the same 2300 transects to calculate short-term (May 2004 to September 2005) storm-driven shoreline change rates as were used in the long-term, pre-storms analysis. However, due to numerous gaps in the post-storm shoreline from island breaching and washover, only about $60 \%$ of the original transects crossed all three lidar shorelines. The data presented are in Universal Transverse Mercator (UTM) projection with the North American Datum of 1983 (NAD83). 
Table 1. Dates and original sources of shorelines for GUIS Santa Rosa Island.

\begin{tabular}{ll}
\hline \multicolumn{1}{c|}{ Date } & \multicolumn{1}{c}{ Original Data Source } \\
\hline $1856,1858,1859$ or 1871 & NOS T-sheets \\
\hline 1934 & NOS T-sheets \\
\hline 1978 & NOS T-sheets \\
\hline 2001 & USGS ATM* lidar \\
\hline May 2004 (2004a) & USGS EAARL ${ }^{*}$ lidar \\
\hline Sept. 2004 (2004b) & USGS EAARL ${ }^{* *}$ lidar \\
\hline Sept. 2005 & USGS EAARL ${ }^{*}$ lidar \\
\hline
\end{tabular}

*ATM: Airborne Topographic Mapper;

**EAARL: Experimental Advanced Airborne Research Lidar

Rates of shoreline change were generated in a GIS with the Digital Shoreline Analysis System (DSAS), an ArcGISC tool developed by the USGS in cooperation with TPMC Environmental Services (Thieler and others, 2005). This tool contains three main components that define a baseline, generate transects perpendicular to the baseline that intersect the shorelines at a user-defined separation along the coast, and calculate rates of change.

Baselines were constructed seaward of, and roughly parallel to, the general trend of the coastline. Using DSAS, transects were spaced at $20 \mathrm{~m}$ intervals. Rates of shoreline change were calculated at each transect using a linear regression rate where there were four or more shorelines and an end point rate for periods when there were three or less shorelines.

\section{Uncertainties and Errors}

Trends and calculated rates of shoreline change are only as reliable as the measurement errors that determine the accuracy of each shoreline position and statistical errors associated with compiling and comparing shoreline positions. A variety of authors have provided general estimates of the typical measurement errors associated with mapping methods and materials for historical shorelines, referencing shoreline position relative to geographic coordinates, and shoreline digitizing (Anders and Byrnes, 1991; Crowell and others, 1991; Thieler and Danforth, 1994; and Moore, 2000).

The largest errors in this analysis were positioning errors of $\pm 10 \mathrm{~m}$, which were attributed to scales and inaccuracies in the original T-sheet surveys. However, the influence of large position errors on long-term rates of change can be reduced if the rate is calculated over a sufficiently long period of time. Additional data source errors implicit in this analysis result 
from GPS positioning errors ( $\pm 1 \mathrm{~m}$ ), which Stockdon and others (2002) associated with the lidar data. Estimates of the maximum measurement errors for this study are provided in Table 2 to show how each error contributes to inaccuracy in the shoreline position.

\section{End-point rate uncertainty}

End-point rates were calculated for those time periods with three or fewer shorelines, and include the 2004a-2004b (Ivan) time period and the 2004b-2005 (Katrina, Dennis, Rita) time period. The total shoreline position error for the end-point retreat rate $\left(E_{a}\right)$ is the quadrature sum of the lidar shoreline position uncertainty $\left(E_{s p}\right)$ for each lidar shoreline divided by the time period over which the rate was determined:

$$
E_{a}=\frac{\sqrt{E_{s p 1}^{2}+E_{s p 2}^{2}}}{\text { time }}
$$

For this analysis, all end-point rates included only lidar shorelines, and each of these has an estimated total positional error of $1.5 \mathrm{~m}$. The shoreline change rate uncertainties were determined to be $2.1 \mathrm{~m} / \mathrm{yr}$ for the end point rates (Table 2 ).

\section{Linear regression (long-term) shoreline change error}

Linear regression is a commonly applied statistical technique for determining rates of shoreline change (Crowell and Leatherman, 1999) where there are a statistically valid number of samples. The long-term rates of shoreline change (1800s to 2004a, and 1800s to 2005) were determined at each transect by taking the slope of the regression line applied to all shoreline positions. The resulting rates are reported in units of $\mathrm{m} / \mathrm{yr}$ (Table 3).

Two uncertainty terms are estimated in the calculation of the long-term shoreline change rates. The first term is the $90 \%$ confidence interval of the linear regression shoreline change rate for each transect. The second term arises from the uncertainty in our best estimates of the proxy bias offsets. We calculate linear regression slopes using shoreline data that have been adjusted based on our best estimate of the shoreline proxy bias as well as data that have been adjusted according to our best estimate of the \pm bias uncertainty. From this analysis we get a best estimate of the shoreline change rate and an uncertainty of the rate due to the bias uncertainty. At each transect we add the regression error and the proxy- 
datum bias uncertainty error to get a total uncertainty of the shoreline change rate at a given location.

However, in terms of calculating regionally-averaged shoreline change rate uncertainties the two terms discussed above need to be treated differently. Because the $90 \%$ confidence interval on the linear regression of each transect is assumed to be random and independent, when averaged over many transects the resulting average uncertainty associated with this term can be quite small; the greater the number of transects over which the uncertainty is averaged, the smaller the uncertainty on the average rate. However, for the second term we need to account for the fact that the proxy-datum offset is a bias and always acts in one direction. Therefore, the regionally averaged shoreline change rate uncertainty associated with the proxy-datum bias is simply the average value of the error resulting from the uncertainty of the proxy-datum bias. The regionally averaged total shoreline change uncertainty terms can be expressed by:

$$
\mathrm{U}=\frac{\sqrt{\sum_{i=1}^{n} C_{i}^{2}}}{n}+\frac{\sum_{i=1}^{n} B_{i}}{n}
$$

where $\mathrm{U}$ is the alongshore averaged shoreline change rate uncertainty, $C$ is the linear regression $90 \%$ confidence interval, $B$ is the shoreline change rate uncertainty associated with the proxy-datum bias, and $n$ is the number of transects included in average. For this study the error associated with the linear regression rates was determined to be $<0.1 \mathrm{~m} / \mathrm{yr}$.

\section{DISCUSSION}

The shoreline change analysis covers a total of approximately $25 \mathrm{~km}$ of Santa Rosa Island. The long-term average rate of shoreline change prior to the 2004-05 storm seasons was $-0.3 \pm 0.1 \mathrm{~m} / \mathrm{yr}$. However, the rates of shoreline change vary dramatically within the two park units. In both the long-term and storm-driven change analyses, rates of change within the Fort Pickens unit were much more variable than those within the Santa Rosa unit. During the hurricanes of 2004 and 2005, the shoreline change rates increased by two orders of magnitude (Table 3 ). Historically, the maximum rate of change, $-1.3 \pm 0.1 \mathrm{~m} / \mathrm{yr}$, was measured within the Fort Pickens unit. The maximum rate of change driven by the storms was $-70.2 \pm 2.1 \mathrm{~m} / \mathrm{yr}$.

Overall, the impacts of the 2004-05 storms to the long-term trends of shoreline change and the mean rates of change in both the FPU and the SRU were variable, and the Santa 
Rosa unit was more greatly impacted, as discussed below. A Student's t-test run on the datasets indicate that there is a statistically significant difference between the 1800 s - May 2004 (pre-Ivan) and the 1800s - Sept. 2005 (post-storms) rates $(p<0.0001)$.

Table 2. Maximum estimated positional errors for GUIS shorelines.

\begin{tabular}{|c|c|c|c|c|}
\hline \multirow{2}{*}{$\begin{array}{l}\text { Shoreline change rate uncertainties } \\
\qquad(\mathrm{m} / \mathrm{yr})\end{array}$} & \multicolumn{4}{|c|}{ Time Period } \\
\hline & $\begin{array}{l}1800 s- \\
2004 a\end{array}$ & $\begin{array}{l}2004 a- \\
2004 b\end{array}$ & $\begin{array}{l}2004 a- \\
2005\end{array}$ & 1800s-2005 \\
\hline Linear regression rate & $<0.1$ & -- & -- & $<0.1$ \\
\hline End point rate & -- & 2.1 & 2.1 & -- \\
\hline
\end{tabular}

Table 3. Average and maximum long-term and storm-associated erosion rates for the Florida GUIS park units. FPU = Fort Pickens Unit; SRU = Santa Rosa Unit.

\begin{tabular}{|c|c|c|c|c|c|c|c|c|}
\hline \multirow[b]{2}{*}{ Unit } & \multicolumn{2}{|c|}{$\begin{array}{c}\text { Long-term (pre-storms) } \\
(1800 \mathrm{~s}-05 / 04) \\
\text { Erosion rate }(\mathrm{m} / \mathrm{yr}) \\
\end{array}$} & \multicolumn{2}{|c|}{$\begin{array}{c}\text { Hurricane Ivan } \\
05 / 04-05 / 05 \\
\text { Erosion rate }(\mathrm{m} / \mathrm{yr}) \\
\end{array}$} & \multicolumn{2}{|c|}{$\begin{array}{c}2004-05 \text { Hurricanes } \\
09 / 04-09 / 05 \\
\text { Erosion rate }(\mathrm{m} / \mathrm{yr}) \\
\end{array}$} & \multicolumn{2}{|c|}{$\begin{array}{c}\text { Long-term (post-storms) } \\
(1800 \mathrm{~s}-2005) \\
\text { Erosion rate }(\mathrm{m} / \mathrm{yr}) \\
\end{array}$} \\
\hline & Av. & Max. & Av. & Max. & Av. & Max. & Av. & Max. \\
\hline$F P U$ & $-0.7 \pm 0.1$ & $-1.3 \pm 0.1$ & $-22.6 \pm 2.1$ & $-43.6 \pm 2.1$ & $-38.5 \pm 2.1$ & $-70.2 \pm 2.1$ & $-0.9 \pm 0.1$ & $-1.5 \pm 0.1$ \\
\hline$S R U$ & $-0.1 \pm 0.1$ & $-0.3 \pm 0.1$ & $-24.6 \pm 2.1$ & $-59.3 \pm 2.1$ & $-35.2 \pm 2.1$ & $-60.3 \pm 2.1$ & $-0.4 \pm 0.1$ & $-0.6 \pm 0.1$ \\
\hline
\end{tabular}

\section{Fort Pickens Unit (FPU)}

The average rate of long-term, pre-storm (1858 - 2004a) shoreline erosion (the average of transects that had negative change) in the FPU was $-0.7 \pm 0.1 \mathrm{~m} / \mathrm{yr}$ (Table 3). The maximum erosion rate during this period, $-1.3 \pm 0.1 \mathrm{~m} / \mathrm{yr}$, occurred near the eastern portion of the unit where the island is narrow (Figure 2a). The long-term, pre-storm shoreline change rates reverse from an erosional trend to an accretional trend at the western end of the FPU where the island width increases to greater than $370 \mathrm{~m}$. Indicative of the documented east-to-west sediment transport direction (Otvos, 1982), the western end of Santa Rosa Island has been prograding over the $\sim 140$ yrs of the study. However, this accretional trend was interrupted during the 2004-05 hurricanes. As a result of storm surge related to Hurricane Ivan, much of this previously stable (or accretional) portion of the FPU became erosional (Figure 2b). 
Large stretches of the FPU were overwashed or completely breached during the 200405 hurricanes and as a result, there are sizable gaps in the shoreline datasets (Figures 2 bd). The overwash/breach areas correspond spatially to the narrowest portions of the island within the FPU.

Average rates of shoreline erosion that resulted from the storms were two orders of magnitude greater than the long-term trends. During the Hurricane Ivan time period, the average rate of erosion increased from the long-term average of $-1.3 \pm 0.1 \mathrm{~m} / \mathrm{yr}$ to $-22.6 \pm 2.1$ $\mathrm{m} / \mathrm{yr}$ and the shoreline erosion associated with both Ivan and the 2005 storms was $-38.5 \pm 2.1$ $\mathrm{m} / \mathrm{yr}$. Although the proximity of the hurricane eye and northeast quadrant to Santa Rosa Island were more favorable for causing high rates of beach erosion during Ivan than those produced during the 2005 storms (Katrina, Rita and Dennis), these storm likely resulted in more damage because the island was decimated by Ivan, and still in a state of recovery when the storms of 2005 occurred.

The combined impact of the 2004-2005 storms on the long-term shoreline change trend was measurable, although not as dramatic as expected, especially in the FPU. The average long-term erosion rate increased by $-0.2 \mathrm{~m} / \mathrm{yr}$ to $-0.9 \pm 0.1 \mathrm{~m} / \mathrm{yr}$, and the maximum rate increased by the same amount to $-1.5 \pm 0.1 \mathrm{~m} / \mathrm{yr}$. The overall patterns of long-term shoreline change within the FPU remained similar (Figure 2d). However, the point of reversal from erosion to accretion near the western end of the park shifted $1 \mathrm{~km}$ to the west in the long-term dataset that include the storms, resulting in a shorter extent of shoreline that is accretional.

\section{Santa Rosa Unit (SRU)}

The shoreline change trends in the SRU are much less variable along-shore than the trends in the FPU. Rates of long-term, pre-storm erosion averaged $-0.1 \pm 0.1 \mathrm{~m} / \mathrm{yr}$, a nonsignificant signal given the uncertainties in the data. The maximum long-term (prestorm) erosion rate was $-0.3 \pm 0.1 \mathrm{~m} / \mathrm{yr}$, and was measured near the western end of the SRU, at one of the narrowest portion of the island within the SRU (Figure 3a). As shown in Figure $3 a$, rates are systematically low throughout this unit, with a slight trend toward erosion at both the east and west ends of the unit, and a slightly more accretional (or less erosional) trend in the center portion of the unit. Spatially, the pattern of shoreline change tends to mimic the shape of the island, with low erosion rates or accretion occurring where the island is wider - in general, at the locations of the bayside cuspate shoreforms. 
Similar to the FPU, rates of shoreline change increased by two orders of magnitude, both from Hurricane Ivan and from the combined impacts of all the 2004-05 storms (Table 3). The shoreline erosion rate associated with Hurricane Ivan averaged $-24.6 \pm 2.1 \mathrm{~m} / \mathrm{yr}$, with a maximum erosion rate of $-59.3 \pm 2.1 \mathrm{~m} / \mathrm{yr}$ located on the eastern end of the SRU, immediately adjacent to the largest breach site, where there is a gap in the shoreline data (Figure 3b). The storms of 2005 resulted in additional areas of overwash and breaching (additional data gaps in Figure 3c). The maximum erosion rate during this period, $-60.3 \pm 2.1$ $\mathrm{m} / \mathrm{y}$ was again located on the eastern end of the SRU, adjacent to a locale that breached during Hurricane Ivan.

Unlike the FPU, the storms of 2004 and 2005 resulted in an overall regime shift in the long-term shoreline change pattern in the SRU (Figure 3d). Whereas the historical pre-storm shoreline change data indicated that this portion of the island was relatively stable, the longterm, post-storm data show an completely erosional regime with erosion rates averaging $0.4 \pm 0.1 \mathrm{~m} / \mathrm{yr}$, and increase of $-0.3 \mathrm{~m} / \mathrm{yr}$.

\section{SUMMARYICONCLUSION}

Long-term ( 140-year) shoreline change rates were generated for the Fort Pickens and Santa Rosa units of GUIS in Florida to assess the historical trends prior to the 2004 and 2005 hurricanes. Results indicate that the rates of shoreline change were higher and more variable in the FPU and that the shoreline was relatively stable within the SRU. In the FPU, the western $1.5 \mathrm{~km}$ of the island had a long-term progradational trend, but the average rate of shoreline erosion for the rest of the unit was $-0.7 \pm 0.1 \mathrm{~m} / \mathrm{yr}$.

Shoreline change rates along the same stretches of coast were calculated to assess the impacts of Hurricane Ivan in 2004 and for the total impacts of the 2005-05 hurricane season, which included Hurricanes Ivan, Cindy, Dennis, Katrina and Rita. During these time periods, the rates of shoreline change increased by two orders of magnitude from the longterm trends. Numerous areas of the island were breached and overwashed, leading to significant gaps in the data, especially within the FPU. In general, these areas tended to correspond to the narrowest portion of the island.

Overall, the average and maximum rates of shoreline erosion were greater in the SRU during the Hurricane Ivan period, which was historically the more stable part of GUIS, and higher in the FPU during the combined periods that include both Ivan and the storms of 2005. This, in part, is likely related to the large data gaps in the FPU, where storm shoreline change rates could not be measured due to breaching or severe island elevation deflation. 


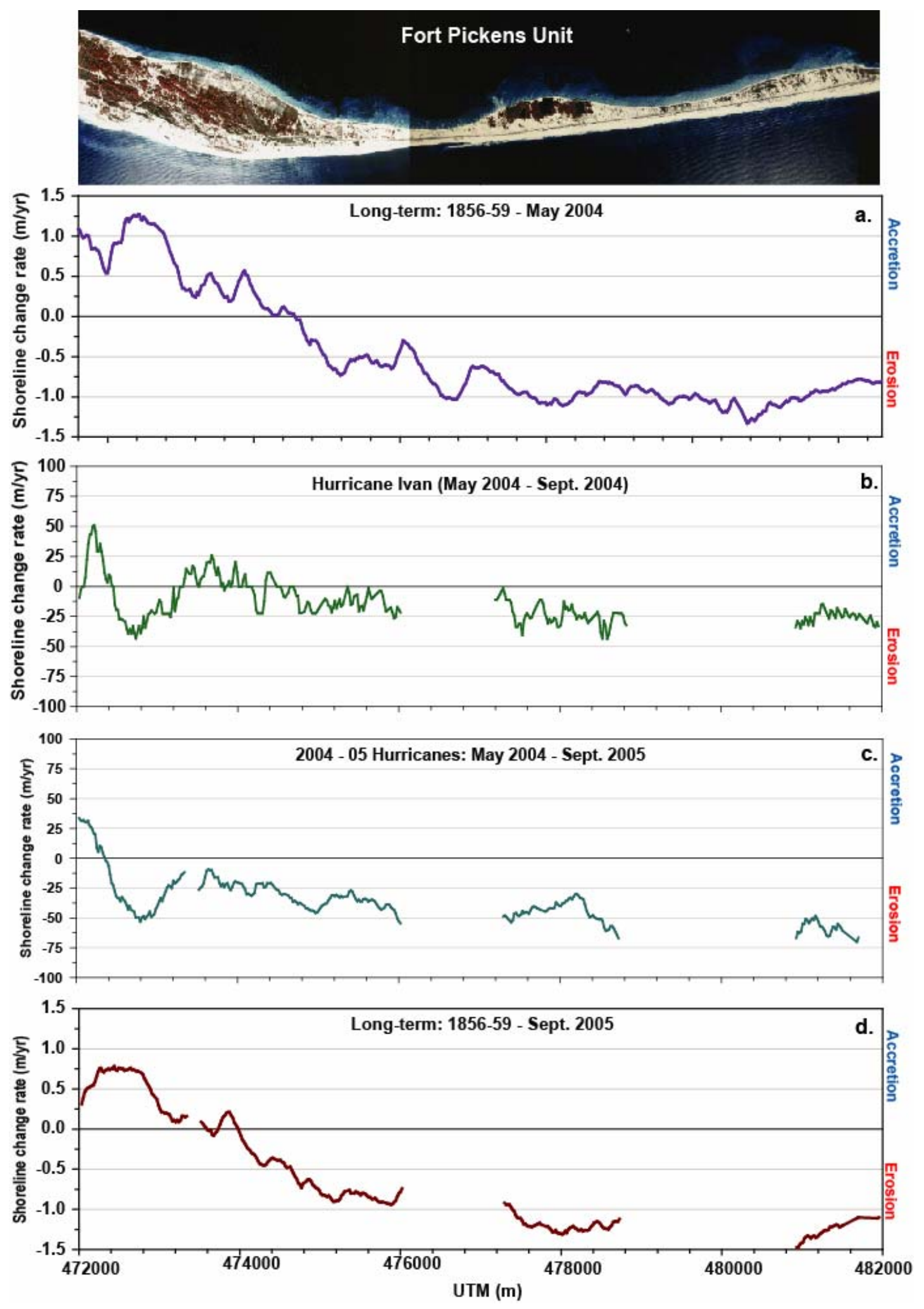

Figure 2. Orthophotomosaic from 1993 and shoreline change plots for the Fort Pickens unit of GUIS. 


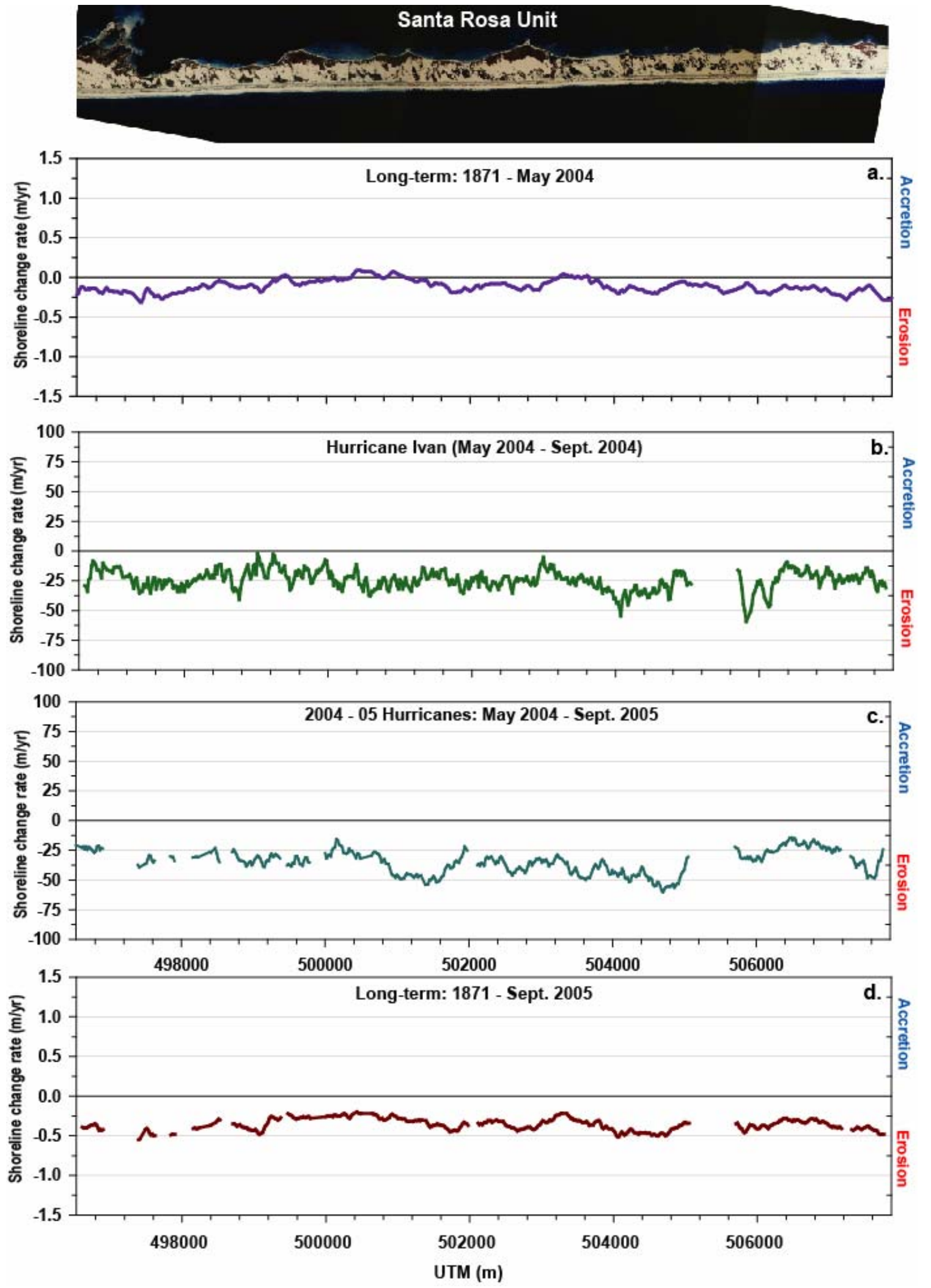

Figure 3. Orthophotomosaic from 1993 and shoreline change plots for the Santa Rosa unit of GUIS. 
Long-term rates of shoreline change were measurably influenced by the 2004 and 2005 hurricanes, although the impacts are greater in the SRU, which has direct park management implications. In the FPU, areas that had high rates of historical erosion prior to the storms were also those areas that experienced high rates of erosion during the storms, and thus the spatial patterns and distributions of shoreline change did not change significantly. One exception is an $\sim 1 \mathrm{~km}$ section of coast in the western half of the FPU where the long-term shoreline change signal reversed from historically prograding to eroding at rates as high as $-0.7 \mathrm{~m} / \mathrm{yr}$. In the SRU, the shoreline shifted from a historically stable system to one that has consistently significant rates of shoreline erosion along its entire length. The shoreline will likely experience rapid recovery in lieu of additional extreme storm events, and an important component of the long-term analysis will be the incorporation of such data as they become available.

\section{ACKNOWLEDGMENTS}

The shorelines from the pre- and post-Ivan lidar were graciously provided by Asbury Sallenger, Hilary Stockdon and Laura Fauver of the USGS Coastal and Marine Geology Program. Additionally, post-Katrina lidar coverage of Santa Rosa Island was made available by John Brock and Amar Nayegandhi of the USGS Center for Coastal and Watershed Studies. Jeff List, Kathy Konicki and Amy Farris (USGS Woods Hole) derived the postKatrina shoreline from lidar data, and calculated the proxy-datum bias. Their contributions were crucial to this study. Funding was generously provided by the National Park Service Natural Resource Preservation Program.

\section{REFERENCES}

Anders, F.J., and Byrnes, M.R., 1991, Accuracy of shoreline change rates as determined from maps and aerial photographs: Shore and Beach, v. 59, p. 17-26.

Crowell, M., Douglas, B.C., and Leatherman, S.P., 1997, On forecasting future U.S. shoreline positions: A test of algorithms: Journal of Coastal Research, v. 13, p. 12451255.

Crowell, M., and Leatherman, S.P., eds., 1999, Coastal erosion mapping and management: Journal of Coastal Research, Special Issue 28, 196 pp.

Crowell, M., Leatherman, S.P., and Buckley, M.K., 1991, Historical shoreline change; Error analysis and mapping accuracy: Journal of Coastal Research, v. 7, p. 839-852.

Miller, T.L., Morton, R.A. Sallenger, A.H., and Moore, L.J, 2004, The National Assessment of Shoreline Change: A GIS Compilation of Vector Shorelines and Associated Shoreline 
Change Data for the U.S. Gulf of Mexico: USGS Open File Report 2004-1089, http://pubs.usgs.gov/of/2004/1089/.

Moore, L. J., 2000, Shoreline mapping techniques: Journal of Coastal Research, v. 16, p. 111-124.

Moore, L., Ruggiero, P., and List. J., 2006, Comparing mean high water and high water line shorelines: Should proxy-datum offsets be incorporated in shoreline change analysis?: Journal of Coastal Research, v. 22, n. 4, p.894-905.

Morton, R.A., Miller, T.L., and Moore, L.J, 2004, National Assessment of Shoreline Change: Part 1, Historical Shoreline Changes and Associated Coastal Land Loss Along the U.S. Gulf of Mexico: USGS Open File Report 2004-1043, http://pubs.usgs.gov/of/2004/1043/.

Otvos, E., 1982, Santa Rosa island, Florida panhandle, origins of a composite barrier island: Southeastern Geology, v. 23, n. 1, p. 15-23.

Shalowitz, A.L., 1964, Shore and sea boundaries. Publication 10-1, U.S. Department of Commerce, Washington, DC, 749 pp.

Ruggiero, P., Kaminsky, G.M., and Gelfenbaum, G., 2003, Linking proxy-based and datumbased shorelines on a high-energy coastline: Implications for shoreline change analyses: Journal of Coastal Research Special Issue 38, p. 57-82.

Stockdon, H.F., Sallenger, A.H., List, J.H. and Holman, R.A., 2002, Estimation of shoreline position and change from airborne topographic lidar data. Journal of Coastal Research, v. 18, p. 502-513.

Stone, G.W., Liu, B., Pepper, D.A. and Wang, P., 2004, The importance of extratropical and tropical cyclones on the short-term evolution of barrier islands along the northern Gulf of Mexico, USA, v. 210, p. 63-78.

Thieler, E.R., and Danforth, W.W., 1994, Historical shoreline mapping (1). Improving techniques and reducing positioning errors: Journal of Coastal Research, v. 10, p. 549563.

Thieler, E.R., Himmelstoss, E.A., Zichichi, J.L., and Miller, T.L., 2005, Digital Shoreline Analysis System (DSAS) version 3.0; An ArcGIS@ extension for calculating shoreline change: U.S. Geological Survey Open-File Report 2005-1304. 